\title{
RIGHT AND OBLIGATIONS OF NOTARIES AS PROTOCOL HOLDERS IN PROVIDING COPIES OF DEEDS TO INTERESTED PARTIES
}

\author{
Cening Mariani*, ORCID ID: 0000-0002-5786-8367, \\ I. Nyoman Putu Budiartha, ORCID ID: 0000-0002-6738-5078, \\ Ni Putu Ayu Sriasih Wesna, ORCID ID: 0000-0002-9283-412X

\begin{abstract}
Warmadewa University Denpasary, Jl. Terompong No.24, Sumerta Kelod, Kec. Denpasar Tim., Kota Denpasar, Bali 80239, Indonesia

*Corresponding author: Cening Mariani, cenigmarani72@gmail.com
\end{abstract}

Received: 12. 17. 2021

Accepted: 01. 27. 2022

\begin{abstract}
Notary protocol is part of the notary office administration which has a very important function and role so that notaries can carry out their positions properly. Notary protocol is a collection of documents constituting state archives which must be kept and maintained by a notary in accordance with statutory regulations. This research raises the formulation of the problem as follows: 1 ) What are the rights and obligations of the notary holder of the Protocol in providing a copy of the deed to interested parties? 2) What is the legal consequence, for the Notary holding the protocol in issuing a copy of the deed, whose minimum document is not fully signed by the parties, and/or witnesses, and/or the Notary Public? This research uses normative legal research, because there is a vacuum of norms regarding the Rights and Obligations of Notary Protocol Holders in Providing Copies of Deeds to Interested Parties. Research using this normative juridical method using the statutory approach, the Conceptual Approach and the Case Approach. Legal materials used are primary, secondary, and tertiary legal materials. An analysis of legal materials is also carried out using several analysis techniques, namely: identifying facts, collecting legal materials, analyzing legal issues, arguing, and providing prescriptions. The results of this study indicate that the Rights and Obligations of the Notary Public Protocol Holder in Providing Copies of Deed to Interested Parties, the Notary is entitled to receive honoraria for legal services rendered to interested parties, both the parties and one of the parties. The amount of honorarium for the notary holder of the protocol is not specified in the applicable regulations, this usually refers to the type of deed he makes.
\end{abstract}

Keywords: Rights and obligations, protocol holder notary, copy of deed, incomplete signatures of the parties or witnesses, and/or notary public.

Rezumat. Protocolul notarial face parte din administrarea biroului notarial care are o funcție și un rol foarte important pentru ca notarii să-și poată îndeplini funcțiile în mod corespunzător. Protocolul notarial este o colecție de documente care constituie arhivele statului care trebuie păstrate de către un notar în conformitate cu reglementările statutare. Această cercetare ridică formularea problemei astfel: 1) Care sunt drepturile și obligațiile 
notarului titular al Protocolului în furnizarea unei copii a actului către părțile interesate? 2) Care este consecința juridică pentru Notarul care deține protocolul în eliberarea unei copii a actului, al cărui document minim nu este semnat în totalitate de părți, și/sau de martori, și/sau de Notarul Public? Această lucrare utilizează cercetarea juridică normativă, deoarece există un vid de norme privind drepturile și obligațiile titularilor de protocol notarial în furnizarea de copii ale actelor către părțile interesate. Cercetarea aplică abordarea statutară, abordarea conceptuală și abordarea cazului. Sunt utilizate materiale juridice primare, secundare și terțiare. $\mathrm{O}$ analiză a materialelor juridice este, de asemenea, efectuată în baza mai multor tehnici de analiză, și anume: identificarea faptelor, colectarea materialelor juridice, analiza problemelor juridice, argumentarea și furnizarea de prescripții. Rezultatele acestui studiu indică Drepturile și Obligațiile Notarului Public Deținător de Protocol în furnizarea de copii ale actului către părțile interesate. Notarul este îndreptățit să primească onorari pentru serviciile juridice prestate părților interesate, atât părților, cât și uneia dintre părți. Cuantumul onorariului pentru notarul titular al protocolului nu este specificat în reglementările aplicabile, acesta se referă la tipul de act pe care acesta îl face.

Cuvinte cheie: Drepturi și obligații, notar titular de protocol, copie act, semnături incomplete ale părților sau martorilor și/sau notar public.

\section{Introduction}

As we have seen, the provisions in Article 1868 of the Civil Code (KUHPerd) are the basis for public officials, namely Notaries who are authorized to make authentic deeds. Evidence in general according to the provisions of Article $1866 \mathrm{KUHPerd}$ is also stated in Article 1867 KUHPerd that proof by writing is carried out in authentic writings or by handwriting. A rule of law has the principle of guaranteeing certainty, order and protection of the law which has the essence of truth and justice. The existence of legal certainty, order and protection can be seen in the traffic of laws of life in society which requires evidence that clearly determines the rights and obligations of a person as a legal subject in society. Laws were made to regulate human life as social beings. In society the law has an important role to play in creating and maintaining security and order.

In social life, legal certainty is needed, including in the public service sector which is currently growing along with the increasing need for the community itself for the existence of a service, this has an impact on the increase in the field of notary services In the service sector, Notaries are given part of the authority by the State to serve the public in the civil sector, especially the making of authentic deeds, and are also given the obligation by the State to become holders of Notary protocols who have entered retirement, Notaries who have passed away, Notaries who have been dismissed with respect or not with respect. Notaries have been entrusted with assisting the public in making authentic deeds in accordance with their functions and objectives.

Generally, the retirement period of a profession, which ends at an average age of 65 years, also applies to the notary profession. Notary who is about to enter retirement, is obliged to notify in writing to the Regional Supervisory Council (MPD) the expiration of the term of office and at the same time propose another notary as the protocol holder within 180 (one hundred and eighty) days or no later than ninety (90) days before the notary public. the person concerned has reached the age of sixty-five (65) years and cannot be extended (regulations of the ministry of Law and Human Rights No. M.01-HT.03.01 Year 2006, 
concerning Terms and Procedures for the Transfer and Dismissal of Notary Public, Article 28 paragraph (1).

The Regional Supervisory Council (MPD) appoints another notary as the protocol holder and submits a letter of appointment to the Minister cq. Director General within fourteen (14) days from the date of receipt of the proposal. If the Regional Supervisory Council (MPD) does not receive a letter of proposal for the appointment of another notary as the protocol holder within fourteen (14) days, the Regional Supervisory Council (MPD) has the authority to propose another notary as the protocol holder to the Minister cq. Director General (regulations of the ministry of Law and Human Rights No.M.01-HT, 03.01, 2006 concerning Requirements and Procedures for the Transfer and Dismissal of Notaries, Article 28 paragraph (2) Paragraph (3) Paragraph (4) and Paragraph (5) [1].

Another notary public notary protocol recipient who is obliged to keep the deed is not responsible for the content of the notary protocol deed he receives. Notaries are directly obliged to the Notary protocol. The death of a notary, apart from leaving problems related to pending work, of course, will also leave other problems related to the notary protocol.

Deeds have the power of proof as deeds under hand with regard to the evidentiary value of a piece of evidence. Underhanded deeds have the power of proof as long as the content and signature included in them are acknowledged by the parties. If one of the parties denies it, the value of proof is left to the judge. A Notary Deed that has the power of proof as an underhand deed can occur if it does not fulfill the provisions as referred to in Article 1869 BW, namely because:

1. The public official concerned is not authorized.

2. Do not have a public official concerned.

3. Defects in shape.

Article 1 number 1 of Law Number 2 of 2014 concerning Amendments to Law Number 30 of 2004 concerning the Position of Notary (hereinafter referred to as UUJN) which states that a Notary is a public official who is authorized to make authentic deeds and has other powers as referred to in Article 15 UUJN. In carrying out his duties and positions, a notary must be guided normatively by the rules of law relating to all actions to be taken which will then be stated in a deed [2]. Acting based on applicable legal rules will certainly provide legal certainty to the parties, that the deed made before or by a notary is in accordance with the applicable legal rules, so that if there is a problem the Notary deed can serve as a guideline for the parties.

Notary is a profession that has special expertise in a special education and training, this requires the Notary to have extensive knowledge and responsibility to serve the public interest. A Notary has guidelines or guidelines in carrying out his position, namely the Code of Ethics and UUJN. The professional code of ethics regulates Notary internally and UUJN externally. In the Code of Ethics, every Notary who carries out his position must not conflict with the regulations made by the competent authority. The Notary Code of Ethics is a moral code determined by the association of the Indonesian Notary Public Association based on a congress decision of the association and/or which is determined and regulated in laws and regulations and is applicable and must be obeyed by individuals and all members of the association and all people who carry out the duties and positions of a Notary. When carrying out their duties, the Notary must uphold and uphold the dignity of his profession as a position of trust and honor. 
In the case of a Notary as the protocol holder who has been appointed by the local Regional Supervisory Council (MPD) and the Notary on his own accord and voluntary. The storage of protocols by the Notary who holds the protocol is an effort to maintain the legal age of the Notary's deed as perfect evidence for the parties or their heirs regarding all matters contained in the deed. So that if there is a Notary who is retired or dies, it is still kept through the Notary protocol [3]. The definition of the Notary protocol in Article 1 number 13 UUJN: "Notary Protocol is a collection of documents which is a state archive that must be kept and maintained by a Notary in accordance with the provisions of the legislation. In the storage of the notary protocol, a careful process is needed so that the notary protocol is not scattered, lost or damaged. The obligation to keep the notary protocol for a period of 25 (twenty five) years. The next obligation of the notary is to submit a report on a list of activities related to the preparation of deeds, letters, and documents which are the authority of the notary every month to the Regional Supervisory Council (MPD) in the work area of the notary concerned and specifically regarding wills to be reported to the Central Register. The will of the Ministry of Law and Human Rights of the Republic of Indonesia.

The protocol belongs to the community, does not belong to the notary who made the deed, and also does not belong to the notary who is assigned/appointed by the Minister of Justice to keep it. A person who keeps a document in the protocol of a notary public generally knows that a document is safe in the hands of a notary public [4]. The large number of recording activities by the notary raises its own problems in terms of storage. The retention period for these archives if they comply with the regulations regarding company documents is at least 30 years. This period of time is not short and along the way there is often a risk of damage or even loss.

There are so many deed archives (minuta) that must be kept and maintained by the Notary Public, has created separate problems for the Notary, not only the Notary who is still in his service period but also up to the next successor notary. The Regional Supervisory Council is not able to store thousands of notary protocols that are over 25 years old in the Regional Supervisory Council office because the Supervisory Council itself does not have an office to store these documents because the MPD has to provide facilities for that and of course it will cost a lot of money so that the notary's protocols are kept at the office of the notary concerned. Constraints faced by protocol holders, namely the issue of where to store protocols, lack of time for MPD to go directly to monitoring the activities of notaries in each of its offices which are spread quite a lot in its area. It is an obligation for the MPD to check the notary protocol periodically at least 2 times a year. The concept of transferring the notary protocol to the protocol holder is in accordance with what is mandated in the Notary Position Regulation (PJN) by producing a Notary Protocol Handover Report witnessed by the local Regional Supervisory Council (MPD). With the rights and obligations of Notary protocol holders not yet regulated in the laws and regulations, the authors are interested in proposing the formulation of the problem as follows:

1. What are the rights and obligations of the notary holder of the Protocol in providing a copy of the deed to interested parties?.

2. What is the legal consequence, for the Notary who holds the protocol in issuing a copy of the deed, whose minimum deed is not complete, the signatures of the parties, and/or witnesses, and/or Notary? 


\section{Research Methods}

Research is a principal means of developing science or technology. This is because research aims to reveal the truth systematically, methodologically, and consistently. The research method is one of the important factors that support a research process, namely in the form of solving a problem to be studied, where the research method is a procedure or steps that are considered effective, efficient and generally for collecting, processing and analyzing data in order to answer problems that are will be researched [5]. The function of the research method is a tool to find out a problem to be studied, both social sciences, law science, and other sciences. Therefore, the objects and types of research will determine the function of a study [6]. The type of research used to solve this problem is a type of normative legal research or doctrinal legal research, also known as library research or document study. This research departs from the absence of norms in UUJN in the absence of regulations governing the rights and obligations of Notary Protocol Holders.

The types of approaches used in this research are:

The statutory approach (The Statute Approach), which is an approach carried out by examining all laws and regulations relating to the issues discussed, the Conceptual Approach, which is an approach that departs from the views and doctrines developed in In law, the Case Approach is used to build legal arguments against cases that are related to the rights and obligations of Notaries as Notary Protocol Holders and their legal consequences.

Sources of legal materials used in this paper use three sources of legal materials, namely: primary sources of legal materials, sources of secondary legal materials, and sources of tertiary legal materials. The legal materials used in this paper were obtained through the collection of legal materials which were carried out by means of library research techniques. Literature study is the study of written information about law that comes from various sources and is widely published and is needed in normative research.

Legal construction analysis is used because of the absence of norms in UUJN, namely the absence of regulating the rights and obligations of notary protocol holders. The need for legal construction that has not been formed in the UUJN and the legal consequences of the protocol holder in terms of issuing a copy of which the minuta deed is incomplete, the signatures of the parties, and or witnesses, and or a notary.

Associated with the legal construction produced based on a judge's decision is a concrete event that can fulfill the demands of justice and benefit justice seekers. Even though the value of the sense of justice and benefit is a very relative measure. The fair value requires that legal events be treated equally, while the measure of the usefulness value lies in the usefulness of law for both justice seekers, law enforcers, legislators, government administrators and the wider community [7].

According to Rudolph von Jhering, as quoted by Ali, there are 3 main requirements for carrying out legal construction, namely: first, legal construction that must be able to cover all areas of positive law. secondly, in the making of construction there should be no logical contradiction in it or it should not refute itself. Third, the construction reflects the beauty factor, namely the construction is not something that is made up and the construction must be able to provide a clear picture of something [8].

The construction of this law can be done using logical thinking:

1. Argumentum per analogy or often called analogy. In analogy, different events are similar, similar or similar which are regulated in the same law. 
2. Legal narrowing/legal concretization. In a legal narrowing, general regulations are applied to specific legal events or relationships with characteristic explanations or constructions.

3. Argumentum a contrario or often called a contrario, namely: Interpreting or explaining laws based on the notion of concrete events governing events regulated in law.

Based on this, it is related to the problems that the author took, in terms of notary protocol obligations, firm and clear laws and regulations that govern it are needed so as to provide a legal theory. The theories used in this thesis research are:

proven legally and correctly in making the deed fulfills the elements of civil error and criminal act. Specifically, criminal sanctions against Notaries are not regulated in UUJN, because the duties and functions of a Notary's office are basically in the realm of administrative law and civil law.

Kranenburg and Vegtig argued that regarding the issue of official accountability there are two underlying theories, namely:

1. The theory of fautes de service, which is a theory which states that losses to third parties are borne by the agency of the official concerned. In its application, the losses incurred are also adjusted for whether the error committed is a serious error or minor errors, where the severity of an error has implications for the responsibility that must be borne [9].

2. The theory of fautes personelles, which is a theory that states that losses to third parties are borne by officials who because the action has caused losses. Liability is also determined for violations committed and the legal consequences that result. Criminal liability can also be imposed on the notary if he commits an administrative error, it is a consequence of the violation that has been committed.

\section{Literature Review}

\section{Authority Theory}

Philipus M. Hadjon, presented three types of authority that originate from statutory regulations. This authority includes [10]:

1. Attributive Authority

Attributive authority is usually outlined or derived from the distribution of state power by the constitution.

2. Mandate Authority

The mandate authority is the authority that comes from the process or procedure of delegation from a higher official or agency to a lower official or agency.

3. Delegative Authority

Delegative authority is an authority that originates from the delegation of a government organ to another organ on the basis of statutory regulations.

Regarding the authority in the power of law in a government, Max Weber has the view that "in legal authority, legitimacy is based on a belief in reason, and laws are obeyed because they have been enacted by proper procedures" (In legal authority, legality is based on reasons belief, and obeyed the law because it has been enforced with proper procedures). In essence, sources of authority can be obtained from statutory regulations, either directly (attribution) or delegation (delegation and sub-delegation), as well as on the basis of assignment (mandate). From the theory presented above, the authority to make decisions can only be obtained in two ways, namely by attribution or by delegation. Attribution is the authority inherent in a position. 


\section{Legal Certainty Theory}

In theory, the state still guarantees legal certainty for the parties in the future in the event of a civil or criminal dispute as stipulated in Article 184 of the Criminal Procedure Code (KUHAP). The principle of a rule of law is to guarantee certainty, order and protection of the law which has the essence of truth and justice.

The theory of legal certainty contains 2 (two) definitions, namely:

1. The existence of general rules makes individuals know what actions may or may not be done.

2. In the form of legal security for individuals from government abuse because with the existence of general legal rules, individuals can know what the State may impose or do against individuals. In relation to legal certainty, according to Gustav Radbruch, law has 3 (three) objectives oriented, namely:

1. Legal certainty,

Legal certainty by everyone can be realized by enacting the law in the event of a concrete event.

2. Justice

Justice is an expectation that must be fulfilled in law enforcement. Based on its characteristics, justice is subjective, individualistic and does not generalize.

3. Benefits

Likewise, on the other hand, if the emphasis is on the value of benefit while legal certainty and justice are put aside, then the law does not work.

\section{Results and Discussion}

The notary whose term of office has ended, notifies the Regional Supervisory Council (MPD) in writing of his term of office and proposes another notary as the holder of the protocol. The transfer of the notary protocol certainly results in the transfer of legal responsibility from the old notary to the notary holding the new protocol. When a notary public retires or resigns from his position as a notary public, the notary deed must be held or kept by another notary as the holder of the notary protocol, and the notary holding the protocol cannot take any action, such as changing the contents of the deed. The transfer of the notary protocol certainly results in the transfer of legal responsibility from the old notary to the notary holding the new protocol.

The rights as holder of the Notary protocol are as follows:

1. The right to receive an honorarium

In issuing a copy at the request of the parties whose names are in the deed or their heirs, the Notary holding the protocol is entitled to receive an honorarium for legal services provided by the parties concerned, whether the parties, one of the parties, the heirs or their proxies. As the holder of the notary protocol, he is indeed entitled to receive an honorarium or compensation for making copies of the deed as requested. The amount of honorarium for a notary as a protocol holder is not specified in the applicable regulations.

2. The Right to Refuse Being a Witness

The holder of the Notary protocol has the right to refuse to be a witness in the trial because the notary granting the protocol has already issued a copy of the previous deed, unless there is permission from the Regional Supervisory Council (MPD) to attend the trial as 
a witness, because in general testimony, it must be a judge or lawyer from both parties. ask to show the deeds that have been made previously by the notary granting the protocol.

3. Right to apply for a protocol deed to be destroyed

In relation to the protocol (the Notary document giving the protocol), the holder has the right to request the Regional Supervisory Council (MPD) to destroy deeds that are more than twenty-five (25) years old. Because the Regional Supervisory Council (MPD) does not have an office for storing State archives (documents), the Notary only follows the existing provisions which require that the Notary Protocol be held by a Notary Public who receives the Protocol at the Notary's office who is appointed as the holder of the Protocol.

4. Right to Refuse to Issue Copies

It is possible that the notary providing the protocol has previously issued a copy.

\section{Obligations of Notaries as Protocol Holders}

1. Provide a copy when someone asks for it according to the provisions

2 Store and care for it in an appropriate place.

3 The holder of the notary protocol is obliged to maintain the security and confidentiality of the deed and its existence (existence).

4 Come and face it if there is a lawsuit (civil or criminal) against the Notary who made it, which is addressed to the Notary holding the protocol as a witness to show his minuta in court with the permission of the Regional Supervisory Council (MPD).

\section{Show Minuta Deed in Court}

In the case of issuing a copy of the deed, if there is a lawsuit from an interested party, the holder of the protocol is obliged to show the minimum amount of the deed at the Court with the permission of the Regional Supervisory Council (MPD). Therefore, the Notary holding the protocol really needs to get legal protection in accordance with their authority.

\section{Facing a Suit}

In practice, notaries and protocol holders are often made or appointed as defendants by other parties, who feel that the legal actions stated in the deed are categorized as legal actions or legal actions of a notary or a notary together with other parties that are also mentioned in the deed. In this matter, is it appropriate to occupy or place a Notary as a defendant in connection with the Notary deed made before or by the Notary concerned and the protocol holder as co-defendant.

As a protocol holder, in issuing a copy of the deed to an interested party it can lead to a lawsuit, namely: Civil Sector: if there is a lawsuit and charges against the protocol holder, the Judge will consider this based on the evidence submitted by both the plaintiff and the protocol holder (defendant/co-defendant)). Criminal Sector: Criminal responsibility to each party for any misuse that is threatened based on criminal provisions (for example: letter forgery, false testimony, illegal access, illegal interception, data and/or system interference, falsification of data, misuse of equipment, distribution of content, illegal, and so on).[11]

Everyone shall be presumed innocent until proven guilt in a free and honest trial in public. This human right is one of the principles in law enforcement mandated by the Criminal Procedure Code, namely: [12]

1. Presumption of innocence or presumption of innocence;

2. A person's guilt must be proven in a fair trial and impartiality;

3. The trial must be open to the public. 
4. The trial must be held without interference from the government or any sociopolitical power

Prodjodikoro, responsibility for a person's actions usually only means that if that person commits an act that is not permitted by law and most of these acts are an act which in the Civil Code is called an act of breaking the law [13]. A Notary Public, if in carrying out his/her duties deliberately commits an act that is detrimental to one or both of the parties that are present in the drawing up of a deed and it can be known that something that is done by the notary for example is contrary to law, then the notary is not can be held accountable under Article 1365 of the Civil Code [14].

The Protocol Holder also cannot be sued based on default because the legal relationship that occurs between the protocol holder and the parties requesting a copy of the deed is not a legal relationship that occurs because of something agreed upon as is usually done by the parties in making an agreement. A notary holding a protocol is a notary who is legally authorized by the Regional Supervisory Council to keep the protocol from a notary. In practice, due to the public's ignorance of the notary holding the protocol and to what extent their responsibility has resulted in several notaries holding the protocol as witnesses, as well as defendants and defendants in court. If the notary holding the protocol is proven to have negligent acts of all his actions, then he is obliged to provide compensation to the injured parties, all of which must be accompanied by strong and accurate evidence.

Prodjodikoro, responsibility for a person's actions usually only means that if that person commits an act that is not permitted by law and most of these acts are an act which in the Civil Code is called an act of breaking the law [13].

A Notary Public, if in carrying out his/her duties deliberately commits an act that is detrimental to one or both of the parties that are present in the drawing up of a deed and it can be known that something that is done by the notary for example is contrary to law, then the notary is not can be held accountable under Article 1365 of the Civil Code [14].

The Protocol Holder also cannot be sued based on default because the legal relationship that occurs between the protocol holder and the parties requesting a copy of the deed is not a legal relationship that occurs because of something agreed upon as is usually done by the parties in making an agreement. A notary holding a protocol is a notary who is legally authorized by the Regional Supervisory Council to keep the protocol from a notary. In practice, due to the public's ignorance of the notary holding the protocol and to what extent their responsibility has resulted in several notaries holding the protocol as witnesses, as well as defendants and defendants in court. If the notary holding the protocol is proven to have negligent acts of all his actions, then he is obliged to provide compensation to the injured parties, all of which must be accompanied by strong and accurate evidence.

Protocol Holder Notary As a Witness, is a person who can provide information for the purposes of investigation, prosecution and trial regarding a criminal case which he has heard himself, has seen and experienced himself. Whereas witness testimony is one of the evidences in a criminal case in the form of testimony from the witness regarding a criminal event that he himself heard, and he experienced himself by mentioning the reasons for his knowledge (Article 1 point 27 of Law No. 8 of 1981). The notary holding the protocol is made or appointed as a witness and then upgraded to suspect status by the investigator, because the legal action that has been taken in providing a copy of the deed does not match the minimum deed or the signature of the parties, and/or witnesses, and/or notary is complete. 
Notary as a Protocol Holder as a Suspect, In determining the Notary holder of the protocol as a suspect in issuing a copy of the deed, the police as an investigator must be careful, have a strong legal basis, both criminal and civil, and the public report cannot be seen with one eye, must see the legal substance of the deed made before the Notary before by the parties as a whole (agregate) and comprehensiveness as well as the position of the protocol holder who only serves as the depositor of the deeds and documents.

Notary Protocol Holder As a Convict, the Convict is "a person who is convicted of a crime and crime by a court" or "a person who has served a sentence." What is meant by a decision that has obtained permanent legal force is a court decision that decides a criminal case at the first level. that is not filed for appeal or cassation, a court decision that decides a criminal case at the appeal level that is not filed for cassation, or an appeal decision.

If a notary or protocol holder is found guilty of committing a criminal act, the Regional Supervisory Council (MPD) will propose to the Minister of Law and Human Rights to revoke his operational license. The sanctions given to the rogue protocol holders are not only those who commit serious crimes, because if they are sentenced to probation, they will be punished firmly, namely revocation of the license. The dismissal of a notary or protocol holder not only violates the law, but can also be the result of committing other disgraceful acts, such as violating religious norms, moral and customary norms, all of which will undermine the honor and dignity of the notary's office.

The elements of a criminal act include:

a. Deeds (human)

Actions are actions and events caused by these acts, human actions in the elements of a criminal act is behavior plus events caused by the behavior [15].

b. Fulfill the formulation of the law (formal requirements)

An action can be said to be a criminal act if it has fulfilled the formulation or elements contained in the regulation. This comes from the legality principle "nullum delictum nulla poena sine pravia lege poenali"

c. It is against the law

In addition to the two elements above, in order to be categorized as a criminal act, it must also fulfill the third element, namely the element against the law, this element is an absolute element of a criminal act.

Indemnity for Negligence

Compensation is to pay all losses due to the destruction or damage of goods belonging to the creditor due to the negligence of the debtor. To demand compensation, there must be a collection or (summons) in advance, except in certain cases that do not require a warning. If the notary holding the protocol is proven to have negligent acts of all his actions, then he is obliged to provide compensation to the injured parties, all of which must be accompanied by strong and accurate evidence. There are several things that the holder of the protocol can be asked for compensation for negligence in keeping the notary protocol, including:

1. Loss of deed minuta;

As a result, the storage place for the minuta deed is not good and inadequate, resulting in the loss of the certificate.

2. Minuta deed is in a damaged condition so that the substance cannot be read;

3. In issuing a copy there is a possibility that the substance (content) does not match or equals the essence; 
4. The holder of the protocol in providing a copy is not careful in issuing a copy where the minimum amount of the act is not signed by the parties or witnesses or a notary.

5. Employees who hold the protocol sometimes make copies of the protocol and give it to unauthorized persons.

In accordance with Article 1365 of the Civil Code, it is explained that every act violating the law, which brings harm to another person, obliges the person who due to his wrongdoing the loss, to compensate the loss. In connection with what is explained above, the protocol holder should pay attention to the above matters to reduce negligence so as not to be trapped by this article.

\section{Conclusion}

From the results of the discussion of this thesis research, it can be concluded several things regarding the rights and obligations of the notary holder of the protocol in providing a copy of the deed to interested parties, which in the provisions of the Law on Notary Position have not been regulated so that there is a norm vacuum. The rights of the Notary Protocol Holder are as follows: Refusing to be a witness in the event that the notary concerned has submitted a copy of the deed, Receiving an honorarium in handing over a copy of the notary's minuta, Refusing to issue a copy, if it is the signature of the parties/one of the parties and/or witnesses and/or incomplete notaries, refuse and ask the MPD to issue a copy of the incomplete signature of the Minuta, have the right to no longer hold the protocol and return the notary protocol to MPD for certain reasons. Meanwhile, the obligations of the notary protocol holder: care for and maintain the protocol and show the minimum deed of a notary in court if necessary in a civil trial, keep and care for it in an appropriate place, maintain security and confidentiality of deeds and documents, face a lawsuit (civil or criminal) against a Notary who make it, which is addressed to the protocol holder. The legal consequence for the Notary who holds the protocol in issuing a copy of the deed, whose minimum deed is not complete, the signature of the parties or witnesses or Notary, namely the notary holder can be a defendant, witness, suspect or convict.

From the problems that the author has conveyed, the authors submit suggestions regarding this writing to: the government together with the People's Representative Council of the Republic of Indonesia (DPR RI) in terms of making a Law on Notary Position (UUJN) in the future must be able to provide legal protection for protocol holders because protocol holders only keep documents (minuta deeds) and their documents, so as to avoid civil lawsuits and criminal reports, the Regional Supervisory Council (MPD) should coordinate with the Ministry of Law and Human Rights (HAM) both in the region and in the ministry. (the center) should provide facilities for storing state deeds (documents), especially notary deed documents, so that the confidentiality of the minimum amount of the deed is maintained, safe from natural disasters and the existence of such state documents.

\section{References}

1. Sulihandari H., \& Rifiani, N. Prinsip-Prinsip Dasar Profesi Notaris. Jakarta: Dunia Cerdas, 2013.

2. Soesanto R. Tugas, Kewajiban dan Hak-hak Notaris, Wakil Notaris. Jakarta: Pradnya Paramita, 1982.

3. Amsyah Z. Manajemen Kearsipan, Jakarta: Gramedia Pustaka Utama, 2005.

4. Kie T.T. Studi Notariat - Serba-serbi Praktek Notaris. Jakarta: Ichtiar Baru Van Hoeve, 2007.

5. Soekanto S. Pengantar Penelitian Hukum. Jakarta: UI Press, 2012.

6. Ali Z. Metode Penelitian Hukum, Jakarta: Sinar Grafka, 2011.

7. Hamidi J. Hermeneutika Hukum (Sejarah, Filsafat \& Metode Tafsir). Malang: Universitas Brawijaya Press, 2011. 
8. Ali A. Menguak Teori Hukum (legal Theory) dan Teory Peradilan (Judicialprudence). Jakarta: Kencana Prenanda Media Group, 2002.

9. Ridwan H.R.I. Hukum Administrasi Negara. Jakarta: Raja Grafindo Persada, 2006.

10. Efendi L. Pokok-Pokok Hukum Administrasi. Malang: Bayumedia Publising, 2004.

11.Edmon M. Notaris dan Transaksi Elektronik: Kajian Hukum Tentang Cyber Notary atau Electronic Notary. Third Printed. Depok: PT. Rajagrafindo Persada, 2018.

12. Kaligis O.C. Perlindungan Hukum, Atas Hak Asasi Tersangka, Terdakwa dan Terpidana. Bandung: Alumni, 2013.

13. Prodjodikoro W.R. Hukum Acara Perdata di Indonesia. Seventh Printed, Bandung: Sumur Bandung, 1983.

14. Djojodirdjo M.A.M. Perbuatan Melawan Hukum. Jakarta: Pradnya Paramitha, 1979.

15. Moeljatno. Asas-Asas Hukum Pidana. Jakarta: Rineka Cipta, 2008.

\section{Laws and Regulations}

1. Indonesia, 1945 Constitution of the Republic of Indonesia.

2. Indonesia, Law Number 30 of 2004 concerning the Position of a Notary. State Gazette of the Republic of Indonesia of 2004 Number 117 and Supplement to the State Gazette of the Republic of Indonesia Number 4432.

3. Indonesia, Law Number 2 of 2014 concerning Amendments to Law Number 30 of 2004 concerning the Position of a Notary (State Gazette of the Republic of Indonesia of 2014 Number 3, Supplement to the State Gazette of the Republic of Indonesia Number 5491).

4. Indonesia, Law Number 2 of 2014 concerning Amendments to Law Number 30 of 2004 concerning the Position of a Notary (State Gazette of the Republic of Indonesia of 2014 Number 3, Supplement to the State Gazette of the Republic of Indonesia Number 5491).

5. Indonesia, Law Number 43 of 2009 concerning Archives (Supplement to the State Gazette of the Republic of Indonesia Number 5071).

6. Indonesia, Civil Code (State Gazette of the Republic of Indonesia Number 127 of 1958).

7. Indonesia, The Criminal Procedure Code (KUHAP) (Supplement to the State Gazette of the Republic of Indonesia Number 3086).

8. Indonesia, The Criminal Code (KUHP) (Supplement to the State Gazette of the Republic of Indonesia Number 1660). 